\title{
PROGRAM VAKSINASI MASAL PADA SISWA SMA, SMK, DAN SLB DI DINAS PENDIDIKAN DAN KEBUDAYAAN PROVINSI NUSA TENGGARA BARAT 2021
}

\author{
Dwi Kartika Cahyaningtyas'), Evi Diliana Rospia1), Desi Rofita1), Indriyanti Makmun"1), \\ Rizkia Amilia1), Ana Pujianti Harahap"), Sella Shafila1) \\ 1)Program Studi Sarjana Kebidanan Fakultas IImu Kesehatan, Universitas Muhammadiyah Mataram \\ Corresponding author : Dwi Kartika Cahyaningtyas \\ E-mail : ayawika99@gmail.com
}

Diterima 16 November 2021, Direvisi 03 Desember 2021, Disetujui 04 Desember 2021

\begin{abstract}
ABSTRAK
WHO (World Health Organization) telah menyatakan Covid-19 sebagai pandemi dunia. Covid-19 masuk ke Indonesia sejak awal tahun 2020 dan angka kejadian dikonformasi positif terus mengalami kenaikan hingga saat ini. Indonesia memiliki rencana memberikan vaksinasi Covid-19 kepada anak-anak berusia 12-17 tahun. semakin lama anak tidak divaksinasi, maka semakin tinggi potensi munculnya varian baru Covid-19 yang lebih mengancam. Tujuan dalam pengabdian masyarakat ini yaitu menjalankan tugas tenaga kesehatan dalam memutuskan mata rantai penularan covid-19. Hal ini juga berdasarkan peraturan pemerintah mengharapkan pelaksanaan proses belajar mengajar dapat berjalan normal kembali dan dengan proses tatap muka. Metode dalam Pelaksanaan kegiatan vaksin menggunakan penyederhanaan 4 meja menjadi 2 meja dengan 2 tahapan yaitu perencanaan dan pelaksanaan kegiatan. Target sasaran pada kegiatan vaksinasi ini adalah 2000 siswa. Hasil pengabdian yang didapatkan bahwa jumlah yang telah melakukan vaksinasi sebanyak 1900 siswa dan 100 siswa yang tunda. Berdasarkan hasil kegiatan pelasanakan pengabdian masyarakat dengan menjalankan program vaksinasi masal pada siswa siswi SMA, SMK dan SLB se-Kota Mataram didapatkan hasil siswa siswi yang telah divaksin sebanyak 1900 siswa dan ditunda untuk melakukan vaksin sebanyak 100 siswa. Adapun faktor penundaan vaksin yaitu tekanan darah yang tinggi, memiliki riwayat penyakit seperti jantung, kanker, gula darah tinggi, sedang tidak dalam keadaan sehat seperti batuk, pilek, demam. Presentasi yang didapatkan pada kegiatan vaksinasi ini sebanyak $95 \%$ dari target yang telah ditetapkan.
\end{abstract}

Kata kunci: anak sekolah; usia 12-17 tahun; vaksinasi; covid-19.

\begin{abstract}
WHO (World Health Organization) has declared Covid-19 a global pandemic. Covid-19 has entered Indonesia since early 2020 and the number of positive confirmed cases continues to increase until now. Indonesia has a plan to give Covid-19 vaccinations to children aged 12-17 years. The longer a child is not vaccinated, the higher the potential for new, more threatening Covid-19 variants to emerge. The purpose of this community service is to carry out the duties of health workers in breaking the chain of transmission of COVID-19. It is also based on government regulations that expect the implementation of the teaching and learning process to run normally again and with a face-to-face process. The method in implementing vaccine activities uses the simplification of 4 tables into 2 tables with 2 stages, namely planning and implementing activities. The target for this vaccination activity is 2000 students. The results of the service found that the number of students who had vaccinated was 1900 students and 100 students who were delayed. Based on the results of community service activities by running a mass vaccination program for high school, vocational and special school students throughout the city of Mataram, it was found that 1900 students had been vaccinated and postponed to vaccinate 100 students. The factors for delaying the vaccine are high blood pressure, having a history of diseases such as heart disease, cancer, high blood sugar, being not in good health such as cough, runny nose, fever. The presentation obtained in this vaccination activity was $95 \%$ of the target that had been set.
\end{abstract}

Keywords: school children; 12-17 years old; vaccination; covid-19.

\section{PENDAHULUAN}

WHO (World Health Organization) telah menyatakan Covid-19 sebagai pandemi dunia (WHO, 2020). Covid-19 masuk ke Indonesia sejak awal tahun 2020 dan angka kejadian dikonformasi positif terus mengalami kenaikan hingga saat ini. Pada bulan oktober 2020, total angka konfirmasi positif di Indonesia adalah 
320 ribu dengan kasus kematian mencapai 11 ribu kematian (Kemenkes, 2020). Antisipasi yang dilakukan Indonesia dengan menerbitkan berbagai kebijakan dalam pengendalian dan pencegahan virus corona. Kebijakan tersebut harus didukung dengan kesadaran masyarakat serta system Kesehatan yang baik (Putri, 2020). Tindakan pencegahan yang dapat dilakukan oleh masyarakat disekitar lingkungannya melalui jaga jarak, menggunakan masker saat keluar rumah dan berkomunikasi, serta selalu menjaga kebersihan tangan dan badan (Prastyowati, 2020).

Pemberian vaksinasi Covid-19 dapat melindungi tubuh, dengan menciptakan respons sectory di tubuh tanpa adanya gejala berat saat tertular virus corona. Sehingga upaya yang perlu dilakukan tenaga medis dalam menurunkan angka kejadian Covid-19 dengan memberikan edukasi kepada masyarakat tentang vaksinasi Covid-19 guna meningkatkan minat dan antusiasme vaksinasi (Hardy, 2020).

$$
\text { Indonesia memiliki rencana }
$$

memberikan vaksinasi Covid-19 kepada anakanak berusia 12-17 tahun. Keputusan yang telah dibuat Badan Pengawas Obat dan Makanan (BPOM) memberikan izin penggunaan darurat vaksin Sinovac pada anakanak (Widjaya, 2020). Berdasarkan hasil uji klinis didapatkan bahwa anak usia 12-17 tahun tidak mengalami demam setelah vaksinasi dengan Sinovac, data imunogenisitas dan keamanan pun meyakinkan, sehingga Ikatan Dokter Anak Indonesia (IDAI) merekomendasikan dua dosis vaksin dengan jarak satu bulan (Harahap, 2020). Kementerian Kesehatan mencatat di Indonesia sebanyak 250,6 ribu kasus positif yang terjadi pada anak. Sebanyak 20,6 ribu diantaranya masih menjalani perawatan di rumah sakit atau isolasi mandiri. Bila dihitung proporsinya, angka kasus yang aktif untuk anak bahkan lebih tinggi daripada lansia, yaitu $13,5 \%$ berbanding $11,2 \%$ (KemenKes, 2021).

Total kasus Covid-19 yang terjadi pada anak di Indonesia yaitu usia 0-2 tahun sebanyak 32.264, usia 3-6 tahun sebanyak 34.941, usia 7-12 tahun sebanyak 70.230, usia 13-15 tahun sebanyak 49.943, usia 16-18 tahun sebanyak 63.232 (Kemenkes, 2021). Menurut Anthony Skelton mengatakan semakin lama anak tidak divaksinasi, maka semakin tinggi potensi munculnya varian baru Covid-19 yang lebih mengancam. Misalnya adanya varian delta merupakan mutase dari varian inggris dan memiliki tingkat penularan $97 \%$ lebih tinggi dari virus corona awal (Affandi et al, 2020).

Satuan Gugus Tugas Covid-19 mengatakan anak memang selalu menjadi kelompok terakhir dalam menerima vaksin. Sebab, kekhawatiran pada efek samping yang bisa mempengaruhi tumbuh kembang anak. Meskipun begitu, vaksin covid-19 buatan Sinovac telah melalui uji klinis dan dipastikan aman untuk anak, serta siap untuk digunakan di Indonesia. Langkah ini penting bagi anak untuk mencegah penularan virus dan dampaknya, juga dapat mempersiapkan anak jika nanti kembali melakukan kegiatan tatap muka (Yuangga et al, 2020).

\section{METODE}

Pengabdian masyarakat yang berlangsung melibatkan Dinas Kesehatan Provinsi NTB. Serta lokasi vasksinasi masal yaitu di Dinas Pendidikan dan Kebudayaan Provinsi NTB, dengan sasaran pemberian vaksin adalah seluruh siswa siswi SMA, SMK, dan SLB seKota Mataram dengan target 2000 siswa siswi, yang dilaksanakan pada 21-22 September 2021 Pukul 08.00 Wita. Hal ini berdasarkan peraturan pemerintah mengharapkan pelaksanaan proses belajar mengajar dapat berjalan normal kembali dan dengan proses tatap muka.Kegiatan vaksinasi Covid-19 tetapi memperhatikan protokol kesehatan selama masa pandemi Covid-19. Adapun metode pelaksanaan dalam kegiatan ini yaitu sebagai berikut:

\section{Perencanaan}

a. Melakukan pelatihan vaksinator yang telah diadakan oleh Dinas Kesehatan Provinsi NTB.

b. Melakukan kegiatan vaksinasi di Dinas Pendidikan dan Kebudayaan sebagai bentuk pengabdian

\section{Pelaksanaan Kegiatan}

Mekanisme/alur pelayanan pemberian vaksinasi Covid-19 baik yang diterapkan oleh Puskesmas, fasilitas pelayanan kesehatan lainnya dari sebelumnya 4 meja menjadi 2 meja, yaitu:

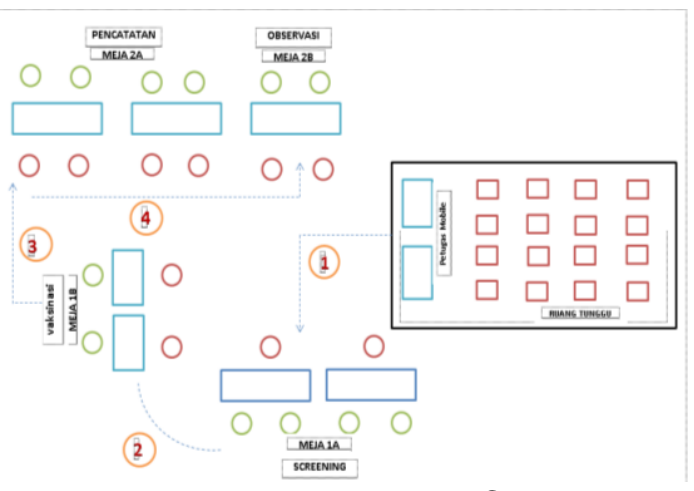

Gambar 1. Alur Vaksinasi Covid-19 
Ruang Tunggu - Petugas Mobil

1) Penerima sasaran yang datang

2) Melakukan pengecekan sasaran melalui pedulilindungi.id (terdaftar/belum), kemudian petugas memeriksan data sasaran yang otomatis telah terdaftar di Aplikasi PCare

3) Membagikan kertas kendali untuk diisi oleh sasaran

4) Bagi sasaran yang belum memiliki aplikasi pedulilindungi maka akan dibantu oleh petugas mobile untuk mengisi secara manual atau dapat dibantu didownload serta diaktifkan di hanphone masing-masing sasaran, selanjutnya memasukkan data tersebut kedalam Aplikasi Pcare

5) Petugas memastikan sasaran menunjukkan nomor tiket elektronik (e-ticket) dan/atau KTP yang digunakan untuk verifikasi data vaksinasi

\section{MEJA 1 Screening - Vaksinasi}

1) Terdiri dari petugas kesehatan minimal 2 orang (petugas screening dan vaksinator)

2) Melakukan screening terhadap sasaran. Screening meliputi : tanda vital dan pertanyaan screening sesuai Juknis

3) Vaksinasi Covid-19 tidak diberikan pada sasaran yang memiliki riwayat konfirmasi Covid-19, memiliki kormobid/riwayat penyakit bawaan (jantung, ginjal, diabetes, dll), kanker,pneumonia, usia dibawah 12 tahun.

4) Peserta yang sudah lolos skrining dapat langsung diberikan vaksin di meja tersebut juga

5) Untuk vaksin mutidosis petugas menuliskantanggal dan jam dibukanya vial vaksin denganpulpen/spidol di label pada vial vaksin

6) Petugas memberikan vaksinasi secara intramuskular sesuai prinsip penyuntikan aman

7) Petugas menuliskan nama sasaran, NIK, nama vaksin dan nomor batch vaksin pada sebuah kertas kendali. Kertas kendali diberikan kepada sasaran untuk diserahkan kepada petugas di Meja 2.

8) Petugas mengisi hasil screening dan vaksinasi pada kertas kendali

\section{MEJA 2 Pencatatan - Observasi}

1) Petugas menerima memo yang diberikan oleh petugas Meja 1

2) Petugas memasukkan hasil vaksinasi yaitu jenis vaksin dan nomor batch vaksin yang diterima masing-masing sasaran ke dalam aplikasi Pcare Vaksinasi

3) Melakukan entri data dari kertas kendali ke dalam aplikasi PCare menggunakan
computer/laptop/HP. Bila tidak memungkinkan untuk menginput data langsung kedalam aplikasi (internet tidak tersedia) maka hasil skrining dicatat dalam format skrining untuk kemudian diinput kedalam aplikasi setelah tersedia koneksi internet.

4) Waktu observasi yang diberikan kepada sasaran sebanyak 15 menit sambal menunggu rekomendasi ITAGI dan KOMNAS KIPI

5) Kartu vaksinasi yang sudah dicetak lebih dahulu diisi dengan ditulis tangan, diberikan penjelasan pada sasaran untuk sertifikat vaksinasi secara otomatis masuk di aplikasi PeduliLindungi atau mendapat sms pada nomor yang aktif.

Rumus Presentasi Vaksin:

$$
P=\frac{f}{n} \times 100
$$

\section{HASIL DAN PEMBAHASAN \\ Hasil}

Selama kegiatan vaksinasi masal, pelaksanaan pengabdian masyarakat memenuhi protokol kesehatan yang sesuai yaitu: memakai masker, mencuci tangan terlebih dahulu, menjaga jarak dan mengurangi jumlah kerumunan. Adapun tahapan-tahapan dalam kegiatan ini yaitu sebagai berikut:

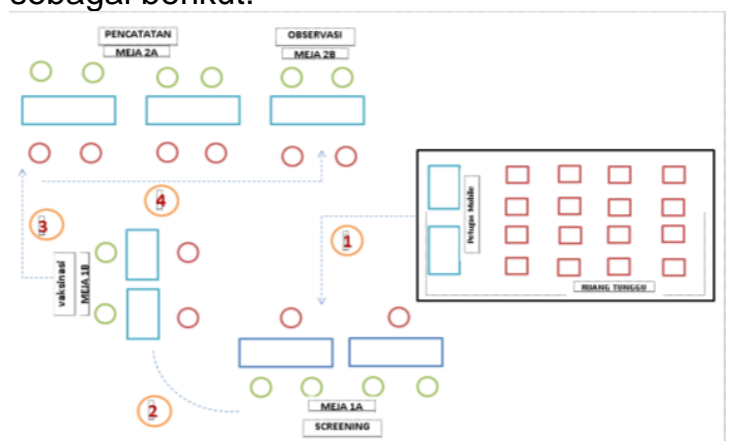

Gambar 2. Alur Vaksinasi Covid-19

\section{Perencanaan}

1) Melakukan pelatihan vaksinator yang diadakan oleh Dinas Kesehatan Provinsi NTB. Pada pelatihan telah dijelaskan rangkaian kegiatan secara menyeluruh mengenai pelaksanaan vaksinasi saat di pelayanan masyarakat. Pada saat akan melakukan layanan vaksinasi di masyarakat diberikan pembekalan awal dengan menjelaskan rangkaian kegiatan secara teknis pelaksanaan.

2) Melakukan kegiatan vaksinasi di Dinas Pendidikan dan Kebudayaan Provinsi NTB sebagai bentuk pengabdian kepada masyarakat.

3) Alur pelayanan vaksinasi Covid-19 dari 
sebelumnya 4 menjadi 2 meja. Penyederhanaan ini untuk menghemat waktu vaksinasi, sheingga lebih efisien dan efektif. Penyederhanaan alur pelayanan vaksinasi ini merupakan komitmen penuh kemeterian kesehatan untuk menghadirkan vaksinasi yang efisien dan efektif, sehingga mampu mengurangi potensi kerumunan akibat dari waktu tunggu yang terlalu lama

\section{Tindakan}

Berdasarkan mekanisme/alur pelayanan pemberian vaksinasi yaitu:

\section{Ruang Tunggu (Petugas Mobile)}

Petugas memanggil sasaran penerima vaksin sesuai dengan kedatangan. Terdapat petugas mobile yang bertugas memeriksa aplikasi pedulilindungi yang telah di daftarkan oleh sasaran vaksinasi, kemudian petugas mobile meminta KTP sasaran dan membuka Aplikasi PCare untuk melakukan verifikasi kecocokan data dengan pedulilindungi. Kemudian petugas meminta KTP kepada sasaran untuk melakukan verifikasi kecocokan data, kemudian petugas memberikan kertas kendali untuk diisi oleh sasaran.
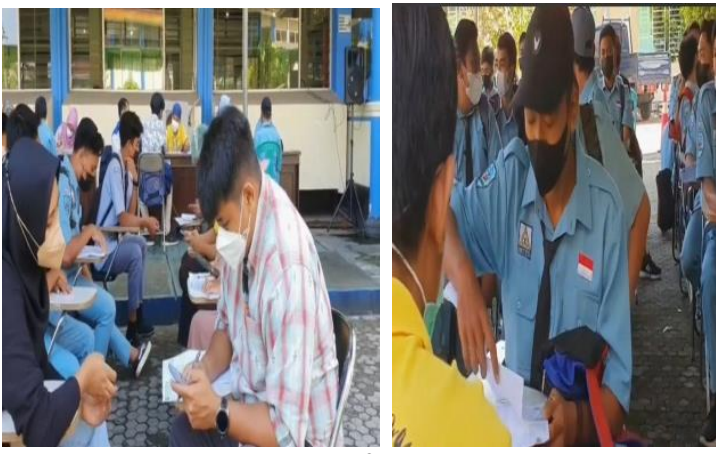

Gambar 1. Pendaftaran Vaksinasi di

PeduliLindungi oleh Petugas Mobile

\section{Meja 1 screening dan vaksinasi}

Petugas memulai tugasnya dengan melakukan anemnesa sebagai dasar melihat kondisi kesehatan dan mengindentifikasi penyakit penyerta (Kormobid), kemudian dilakukan sreening dengan memeriksa suhu tubuh, tanda-tanda vital. Selanjutnya mengisi hasil pemeriksaan kedalam kertas kendali. Jika peserta lolos screening akan langsung diarahkan untuk pemberian vaksinasi Covid-19. Petugas memberikan vaksinasi secara intramuscular, kemudian petugas akan menuliskan nama sasaran, NIK, Nama vaksin, nomorbatch.

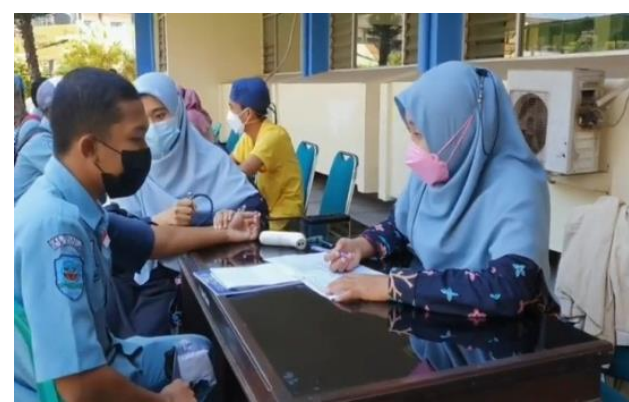

Gambar 2. Tindakan Screening (TD, Suhu) dan pengisian Form Vaksinasi

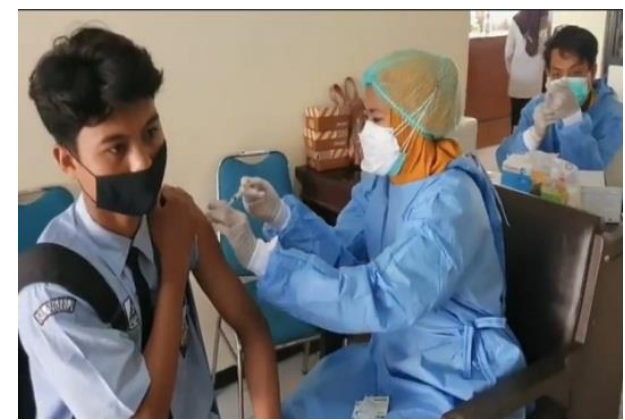

Gambar 3. Tindakan Vaksinasi pada SiswaSiswi SMA,SMK, dan SLB

\section{Meja 2 pencatatan dan observasi}

Petugas menerima kertas kendali dari sasaran dan saran dipersilahkan menunggu 15 menit diruang observasi, kemudian petugas memasukkan kedalam aplikasi Pcare hasil vaksinasi dari jenis vaksin, nomor batch vaksin dan hasil observasi pada sasaran. Lalu sasaran diberikan penyuluhan dengan media KIE tentang pencegahan Covid-19, setelah 15 menit observasi Sasaran akan diberikan kartu vaksin.

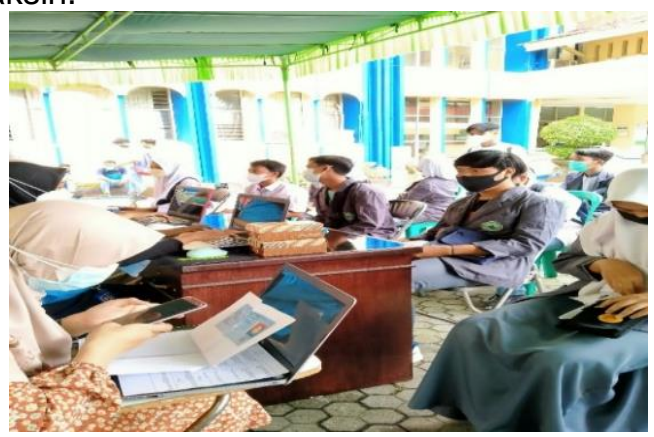

Gambar 4. PencatatanPasca Vaksinasi kedalam Aplikasi Pcare 


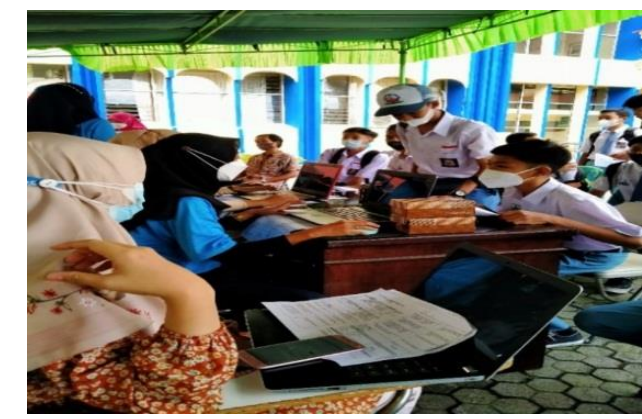

Gambar 5. Observasi Pasca Vaksinasi dan Penerimaan Kartu Vaksin

Hasil pengabdian masyarakat yang didapatkan pada kegiatan vaksinasi masal sejumlah 1900 siswa yang terdiri dari anak sekolah SMA, SMK, dan SLB se-Kota Mataram, dan ditunda umtuk melakukan vaksinasi sebanyak 100 siswa, dikarenakan hasil menunjukkan tekanan darah tinggi, sedang tidak dalam keadaan sehat, batuk, pilek, demam, memiliki riyawayat penyakit jantung, kanker dll.

\section{PEMBAHASAN}

Pemerintah

membuat berbagai

kebijakan guna melindungi masyarakat dari penularan dan dampak Covid-19 mulai dari pembatasan sosial berskala besar termasuk pembatasan sekolah, tempat kerja, tempat peribadatan, tempat umum dan trasnportasi, pemberian bantuan sosial, pemberian insentif bagi tenaga kesehatan, kebijakan penggunan masker dan kebijakan mematuhi protocol kesehatan diberbagai tempat (Report, PP PRIMA DMI 2021). Vaksinasi awal pada periode pertama telah diberikan bulan Agustus 2021 yang diprioritaskan kepada kelompok tenaga kesehatan dan petugas publik. Selanjutnya periode kedua dilakukan pada kelompok lansia dan periode ketiga pada kelompok remaja.

- Sejak mulai adanya pemberian vaksin Covid-19 di Indonesia, tidak sedikit masyarakat yang belum setuju akan anjuran pemerintah untuk menjalani vaksinasi Covid-19 (Marwan, 2021). Pemberian vaksin sangatlah penting, bukan hanya untuk melindungi masyarakat dari Covid-19, tetapi juga memulihkan kondisi sosial dan ekonomi negara yang terkena dampak pandemi (Zahrotunnimah, 2020). Adapun rasionalisasi dan tantangan untuk vaksinasi Covid-19 pada anak dan remaja. Salah satu rasionalisasi vaksinasi Covid-19 pada anak adalah melindungi populasi yang retan terhadap Covid-19. Berdasarkan data saat ini, anak yang dikonformasi positif Covid-19 dapat menularkan ke anak lain maupun orang dewasa disekitarnya. Sehingga populasi anak dan remaja saat ini dimasukkan kedalam uji klinis vaksin Covid-19 (Jenco, 2021).
Hasil pengabdian masyarakat yang telah dilakukan dalam program vaksinasi covid-19 pada siswa SMA, SMK, dan SLB se-Kota Mataram didapatkan presentasi dari target yang ingin dicapai dalam program vaksinasi saat ini sebanyak 95\%. Berdasarkan hasil kegiatan pelasanakan pengabdian masyarakat dengan menjalankan program vaksinasi masal pada siswa siswi SMA, SMK dan SLB se-Kota Mataram didapatkan hasil siswa siswi yang telah divaksin sebanyak 1900 siswa dan ditunda untuk melakukan vaksin sebanyak 100 siswa. Adapun faktor penundaan vaksin yaitu tekanan darah yang tinggi, memiliki riwayat penyakit seperti jantung, kanker, gula darah tinggi, sedang tidak dalam keadaan sehat seperti batuk, pilek, demam.

Hal tersebut sesuai dengan WHO bahwa vaksinasi hanya diberikan untuk mereka yang sehat. Adapun beberapa kriteria yang tidak boleh divaksinasi Covid-19 yaitu orang yang sedang demam dengan suhu $>37,5^{\circ} \mathrm{c}$, hipertensi dengna tekanan darah $>180 / 110$ $\mathrm{mmHg}$, memiliki alergi berat, mengidap penyakit autoimun seperti asma, lupus, memiliki penyakit jantung, memiliki kelainan darah, mendapat pengobatan immunosupressant seperti kortikosteroid dan kemoterapi (WHO, 2021). Kontraindikasi pada vaksin Sinovac usia anak 12-17 tahun adalah defisiensi imun primer, penyakit imun tidak terkontrol, acute demyelinating encephalomyelitis, anak dengan kanker, kemoterapi/radioterapi, sedang menjalani pengobatan imonosupresan, demam $>37,5^{\circ} \mathrm{C}$, hipertensi tidak terkendali, penyakit kronik atau kelainan kongenital tidak terkendali (IDAI, 2021).

Obervasi yang telah dilakukan dalam 15 menit pasca vaksinasi dari seluruh siswa-siswi yang telah mendapatkan vaksin ada beberapa siswa yang mengalami KIPI (kejadian ikutan pasca imunisasi) sebanyak 13 siswa-siswi dalam kategori ringan seperti nyeri bekas suntikan, sakit kepala, pegal pada otot atau sendi, lelah. Hal tersebut sebanding dengan rekomendasi pemberian vaksin Covid-19 pada anak telah dianjurkan secara international dan nasional. CDC menganjurkan pemberian vaksin Pfier-Biontech pada populasi anak, akan tetapi Indonesia sesuai BPOM dan IDAI mengeluarkan rekomendasai pemberian vaksin Sinovac pada anak usia 12-17 tahun. Dikarenakan KIPI yang dilaporkan termasuk ringan-sedang dengan gejala demam dan nyeri di lokasi suntikan. Dosis yang diberikan sama speerti orang dewasa 2 kali penyuntikan dengan jarak 1 bulan, diberikan sebanyak 3 mikrogram (CDC, 2021). 


\section{SIMPULAN DAN SARAN}

Kegiatan pemberian vaksinasi Covid19 pada remaja merupakan upaya utuk memutuskan mata rantai penularan corona virus. Pemberan vaksinasi Covid-19 pada anak sekolah dinilai penting dikarenakan berpotensi menjadi sumber penularan bagi masyarakat sekitar. Langkah ini ditempuh oleh pemerintah sebagai bentuk kebijakan mencegah penularan virus serta mempersiapkan anak sekolah Kembali melakukan kegiatan tatap muka. Jumlah yang melakukan sasaran vaksinasi sebanyak 1900 siswa dan ditunda sebanyak 100 siswa namun ditundah tidak dimasukkan kedalam aplikasi PCare. Pemberian vaksinasi diharapkan dapat bekerjasama dengan fasillitas kesehatan, Dinas Kesehatan, Dinas Pendidikan dan kebudayaan, serta instansi Pendidikan kesehatan dalam meningkatkan sasaran vaksinasi pada anak atau remaja dengan usia 12-15 tahun yang belum terlaksana.

\section{UCAPAN TERIMAKASIH}

Tim penulis mengucapkan terima kasih kepada Dinas Kesehatan Provinsi NTB dan Dinas Pendidikan dan Kebudayaan, serta Lembaga Penelitian dan Pengabdian Masyarakat Universitas Muhammdiyah Mataram dan mitra Pengabdian Masyarakat yang telah mendukung dan memfasilitasi kegiatan pengabdian sehingga kegiatan dapat berjalan dengan lancar.

\section{DAFTAR RUJUKAN}

Affandi, A., Sarwani, A. S., Erlangga, H., Siagian, A. O., Purwanto, A., Effendy, A. A.,\& Wahyitno, C. D. M. (2020). Optimization of MSMEs Empowerment in Facing Competition in the Global Market during the COVID-19 Pandemic Time. Systematic Reviews in Pharmacy, 11(11), 1506-1515.

Center for Disease and Control Prevention. COVID-19 Vaccines for Children and Teens. Mei, 2021. Tersedia di: https://www.cdc.gov/coronavirus/2019ncov/vaccines/recommendations/adoles cents.html

Harahap, M. H., Fibriasari, H., Ihsan, M., Irfand, I., Panggabean, D. D., \& Syah, D. H. (2020). Upaya Peningkatan Pola Hidup Bersih Sehat Di Desa Ibus Melalui Diseminasi Teknologi Tepat Guna Filter Air, Cuci Tangan Digital Dan Mesin Pembuat Sabun Untuk Menghadapi Pandemi Covid-19. Jurnal Pengabdian Kepada Masyarakat, 26(4), 236-240
Hardy, F. R. (2020). Herd Immunity Tantangan New Normal Era Pandemi Covid-19. Jurnal IImiah Kesehatan Masyarakat.

Ikatan Dokter Anak Indonesia. Rekomendasi Ikatan Dokter Anak Indonesia Terkait Pemberian Vaksin COVID-19 pada Anak dan Remaja. Juni, 2021. Tersedia di: https://www.idai.or.id/tentangidai/pernyat aan-idai/rekomendasi-ikatan-dokter anak-indonesia-terkait-pemberianvaksincovid-19-pada-anak-dan-remaja

Jenco M. AAP helps pediatricians prepare to vaccinate children, adolescents against Covid-19. AAP News. 2021:1-3

Marwan. Peran Vaksin dalam Penanganan Pandemi C19. Samarinda: 2021.

Reuters. Oxford University pauses pediatric clinical trial of AstraZeneca covid vaccine. Apr 7, 2021. Tersedia di: https://www.livemint.com/science/health/ oxford-halts-dosing-in-trial-of astrazeneca-covid-vaccine-in-children teenagers-11617756741977.html

Widjaja, S. (2020). Vaksinasi Measles, Mumps, dan Rubella (MMR) Sebagai Prophylaxis Terhadap COVID-19. KELUWIH: Jurnal Kesehatan dan Kedokteran

World Health Organization. Vaccine Safety Bassics (Dasar-Dasar Keamanan Vaksin). Modul 1. WHO; 2021

Yuangga, K. D., \& Sunarsi, D. (2020). Pengembangan media dan strategi pembelajaran untuk mengatasi permasalahan pembelajaran jarak jauh di pandemi covid-19. JGK (Jurnal Guru Kita), 4(3), 51-58.

Zahrotunnimah Z. Langkah Taktis Pemerintah Daerah Dalam Pencegahan Penyebaran Virus Corona Covid-19 di Indonesia. SALAM: Jurnal Sosial Dan Budaya Syari 2020; 7: 247-60. https://doi.org/10.15408/sjsbs.v7i3.1510 3.

Zendrato, W. (2020). Gerakan mencegah daripada mengobati terhadap pandemi covid-19. Jurnal Education and development, 8(2), 242-242 